\title{
Synthesis of Fluorinated Heterobicyclic Nitrogen Systems Containing 1,2,4-Triazine Moiety as CDK2 Inhibition Agents
}

\author{
Mohammed Saleh Tawfik Makki*, Reda Mohammdy Abdel-Rahman, \\ Faisal Mohammed Aqlan \\ Department of Chemistry, Faculty of Science, King Abdulaziz University, Jeddah, Saudi Arabia \\ Email: ${ }^{\text {rm rahman1951@yahoo.com }}$
}

Received 17 August 2015; accepted 25 September 2015; published 28 September 2015

Copyright (C) 2015 by authors and Scientific Research Publishing Inc.

This work is licensed under the Creative Commons Attribution International License (CC BY). http://creativecommons.org/licenses/by/4.0/

c) (7) Open Access

\section{Abstract}

New fluorine substituted heterobicyclic nitrogen system as imidozolopyrimidines $(2,3)$, pyrimido1,2,4-triazinones (4-7), 1,2,4-triazinyl-1,2,4-triazine (12-16), 1,2,4-triazinyl-1,2,4-triazinones (1417) and substituted thiobarbituric acids (19-20), have been synthesized using the reaction of 3 amino-5,6-di (4'-fluorophenyl)-1,2,4-triazine (1) with $\alpha, \beta$-bifunctional compounds. Structures of the title compounds were characterized by UV, IR, ${ }^{1} \mathrm{H} /{ }^{13} \mathrm{C}-\mathrm{NMR}$ and mass spectrometric method. The studied compounds were tested for CDK2 inhibiting activity in DNA damage, as well as in vitro anti-tumor activity.

\section{Keywords}

Synthesis, Fluoroheterobicyclic Nitrogen, CDK2 Inhibition, Anti-Tumor Activity

\section{Introduction}

1,2,4-triazines and their condensed analogues have shown to display wide-ranging applications in medicinal and pharmaceutical chemistry. The NCNN group of 1,2,4-triazine ring is an essential part in various biological activities. Tirapazamine as antitumor [1], Lamotrigine as anti-epileptic drug [2], and fused 1,2,4-triazines as antimicrobial [3]-[5], anti HIV [6] antimycobacterial [7], antiviral [8] [9], anxiolytic [10] and antidepressant [11] agents are already reported in literature. Heterobicyclic nitrogen systems containing 1,2,4-triazine moiety have also shown anti-HIV and anticancer activities [12]-[16]. However, introduction of fluorine atoms to these bioactive heterocycles often improves their pharmacological properties mainly due to increased membrane permeability,

*Corresponding author.

How to cite this paper: Makki, M.S.T., Abdel-Rahman, R.M. and Aqlan, F.M. (2015) Synthesis of Fluorinated Heterobicyclic Nitrogen Systems Containing 1,2,4-Triazine Moiety as CDK2 Inhibition Agents. International Journal of Organic Chemistry, 5, 200-211. http://dx.doi.org/10.4236/ijoc.2015.53020 
enhanced hydrophobic bonding and stability against metabolic transformation owing to the strength of the C-F bond [17]-[21]. Also, introduction of fluorine in these heterobicyclic systems exhibited enhanced anti-tumor activity [20]. The search for novel cancer treatment has however entered a new post-genomic era and the emphasis now is on influencing cell signaling mechanisms such as those triggered by kinases [22] where selective inhibition of the Kinome constituents and related signaling proteins has opened up a diversity of new drug targets.

Cyclin-Dependent Kinases (CDKs) are families of serine/threonine kinases that play a well-established role in the regulation of the eukaryotic cell division cycle and have also been implicated in the control of gene transcription and other processes [23]. Dysregulation of cell cycle in cancer cells has provided a rationale for the development of small molecule inhibitors of CDK1 as novel anticancer drugs. It was believed that CDK2 was the master regulator of S phase entry. Gene knockout mouse studies of cell cycle regulators revealed that CDK2 is dispensable for $\mathrm{S}$ phase inhibition and progression whereby CDK1 can compensate for the loss of CDK2 and the latter was found to be involved in cell cycle independent functions such as DNA damage repair [24].

Rational approaches to the design of fluorine-containing potential inhibitors associated with the strategic placement of fluorine in these molecules led us to design CDK2 inhibitors as possible anti-cancer agents. The aim of the present work is to synthesize and develop fluorinated fused and/or isolated heterobicyclic nitrogen systems, derived from the interaction between 3-amino,6-(4'-fluorophenyl)-1,2,4-triazines (1) and $\alpha$, $\beta$-bifunctional oxygen, sulfur, halogen and nitrogen compounds. In this work, we evaluate the protein kinase inhibiting and cytotoxic activity of fluorinated heterobicyclic systems containing 1,2,4-triazine moiety.

\section{Experimental}

\subsection{Chemicals and Methods}

Melting points were determined using an electrothermal Bibby Stuart Scientific melting point apparatus and are uncorrected. The infrared (IR) spectra were recorded on a Perkin-Elmer FT-IR infrared spectrophotometer using the $\mathrm{KBr}$ pellet technique. Electronic absorption spectra were recorded in DMF using a Shimadzu UV-Visible 1650 PC spectrophotometer. ${ }^{1} \mathrm{H}$ and ${ }^{13} \mathrm{C}$ NMR spectra were recorded on a Bruker DPX-400 FT NMR spectrometer using tetramethylsilane ( internal standard DMSO- $d_{6}$ ) as a solvent (Chemical shifts in $\delta$, ppm). ${ }^{19} \mathrm{~F} \mathrm{NMR}$ Spectra were determined at $84.25 \mathrm{MHz}$ using hexafluorobenzene as a solvent. Splitting patterns were designated as follows: $s$ : singlet; $m$ : multiplet. Mass spectra were measured on a GCMS-Q 1000 Ex spectrometer. Elemental analyses were performed on a 2400 Perkin Elmer Series 2 analyzer and the found values were within $\pm 0.4 \%$ of the theoretical values. Follow up of the reactions and checking the homogeneity of the compounds were made by TLC on silica gel-protected aluminum sheets (Type 60 F254, Merck) and the spots were detected by exposure to UV-lamp.

\subsubsection{3-Amino-5,6-di(4'-fluorophenyl)-1,2,4-triazine (1)}

A mixture of 4,4'-bifluorobenzil ( $0.01 \mathrm{~mol})$ and aminoguanidine bicarbonate $(0.01 \mathrm{~mol})$ in n-butanol [28] was refluxed for $4 \mathrm{~h}$. The solid obtained after cooling the mixture was filtered and crystallized from ethanol to give orange crystals, yield $75 \%$, m.p. $208^{\circ} \mathrm{C}-209^{\circ} \mathrm{C}$. IR $\left(v / \mathrm{cm}^{-1}\right)$ : $3200\left(\mathrm{NH}_{2}\right), 1620$ (deformation, $\left.\mathrm{NH}_{2}\right), 1600$ $(\mathrm{C}=\mathrm{N}), 1250(\mathrm{C}-\mathrm{F})$ and 880, 820 (p-substituted phenyl). ${ }^{1} \mathrm{H}-\mathrm{NMR}$ (DMSO $\left.\mathrm{d}_{6}\right) \delta: 2.89-2.51$ (br. s, 2H, $\mathrm{NH}_{2}$ ), 7.31 - 7.39, 7.39 - 7.44 (each m, 8H, aromatic protons), 7.0 - 6.61 (m). ${ }^{13} \mathrm{C}-\mathrm{NMR}$ (DMSO d $\left.\mathrm{d}_{6}\right) \delta: 164,156,148$, 136 - 131, 129.8 - 127.7. Anal. Calcd: C, 63.15; H, 3.40; N, 21.67; F, $11.76 \%$ for $\mathrm{C}_{17} \mathrm{H}_{5} \mathrm{~N}_{5} \mathrm{~F}_{2}$ (323). Found: C, 62.98; H, 3.25; N, 21.50; and F, 11.6\%.

\subsubsection{3-Amino-5,7-di(4'-fluorophenyl)imidazo[3,2-b][1,2,4-] triazine (2)}

A mixture of $1(0.01 \mathrm{~mol})$ and chloroacetonitrile $(0.01 \mathrm{~mol})$ in DMF was refluxed for $4 \mathrm{~h}$. The solid obtained on cooling the reaction mixture was filtered and crystallized from dioxan to give $\mathbf{2}$ as yellowish crystals, yield $70 \%$, m.p. $141^{\circ} \mathrm{C}-142^{\circ} \mathrm{C}$. IR $\left(v / \mathrm{cm}^{-1}\right)$ : 3350, $3228\left(\mathrm{NH}_{2}, \mathrm{NH}\right), 31.86$ (aromatic $\mathrm{CH}$ ), 1623 (deformation $\mathrm{NH}_{2}$ ), 1601, 1517 (C=N), 1350 (NCN), 1226 (C-F). ${ }^{1} \mathrm{H}-\mathrm{NMR}\left(\mathrm{DMSO} \mathrm{d}_{6}\right) \delta$ : 7.89, 7.4, 7.37, 7.28, 7.24, 7.166, 7.00 and 6.94 (m, 8H, aromatic protons), 6.89, 6.717 (d, d of H adjacent of F), $4.01-3.97\left(\mathrm{~s}, 2 \mathrm{H}, \mathrm{NH}_{2}\right) .{ }^{13} \mathrm{C}-\mathrm{NMR}\left(\mathrm{DMSO} \mathrm{d}_{6}\right)$ $\delta:$ 164, 155, 147, 132, 131 - 130.4, 115, 114, 77.88 - 77.46, 59.68. M/S (Int. \%): 323 (8.89), 282 (33.01), 214 (100). Anal. Calcd: C, 62.96; H, 3.08; N, 17.28; F, 11.72\%; for $\mathrm{C}_{17} \mathrm{H}_{10} \mathrm{~N}_{4} \mathrm{~F}_{2} \mathrm{O}$ (324). Found: C, 62.79; H, 2.88; N, 17.15; and F, $11.55 \%$. 


\subsubsection{6,7-Di(4'-fluorophenyl)-2,3-dihydro-3-oxo-imidazo[3,2-b][1,2,4-]triazine(3)}

A mixture of $1(0.01 \mathrm{~mol})$ and monochloroacetic acid $(0.01 \mathrm{~mol})$ in DMF was heated for $15 \mathrm{~min}$. and then left to cool at room temperature. The solid obtained was filtered and crystallized from dioxan to give $\mathbf{3}$ as faint yellowish crystals, yield $65 \%$, m.p. $193^{\circ} \mathrm{C}-194^{\circ} \mathrm{C}$. IR $\left(v / \mathrm{cm}^{-1}\right)$ : $3090(\mathrm{ArCH}), 1640(\mathrm{C}=\mathrm{O} \leftrightarrow \mathrm{C}-\mathrm{OH}), 1480$ (deformation $\mathrm{CH}_{2}$ ), 2950 (aliphatic CH), $1350(\mathrm{NCN})$, and 1227 (C-F). ${ }^{1} \mathrm{H}-\mathrm{NMR}\left(\mathrm{DMSO} \mathrm{d}_{6}\right) \delta$ : 7.61, 7.41, 7.39, 7.38, 7.32, 7.31, 7.306 and 7.301 (m, 8H, aromatic protons), $7.29(\mathrm{~s}, 1 \mathrm{H}, \mathrm{CH}=), 6.98-6.97,6.95$ and 6.54 (d, $\mathrm{d}$ of $\mathrm{H}$ adjacent of F), $2.52-2.51$ (s, 2H, $\mathrm{CH}_{2}$ ). ${ }^{13} \mathrm{C}-\mathrm{NMR}\left(\mathrm{DMSO} \mathrm{d}_{6}\right) \delta: 164,155,147,132.1,131-130.4,115,114$ and 77.77 - 77.34. Anal. Calcd: C, 62.96; $\mathrm{H}, 3.08$; N, 17.28; F, 11.72\%; for $\mathrm{C}_{17} \mathrm{H}_{10} \mathrm{~N}_{4} \mathrm{~F}_{2} \mathrm{O}$ (324). Found: C, 62.76; $\mathrm{H}, 2.91$; N, 17.01; and F, 11.55\%.

\subsubsection{7,8-Di(4'-fluorophenyl)-2,3-dihydro-pyrimido[3,2-b][1,2,4-]triazin-2,4-dione (4)}

A mixture of $1(0.01 \mathrm{~mol})$ and diethylmalonate $(0.01 \mathrm{~mol})$ in THF was refluxed for $4 \mathrm{~h}$. On cooling the reaction mixture, a yellowish solid separated which was crystallized from THF to give $\mathbf{4}$ as yellow crystals, yield $72 \%$, m.p. $199^{\circ} \mathrm{C}-200^{\circ} \mathrm{C}$. UV (EtOH): $\lambda_{\max } 346 \mathrm{~nm}$. IR $\left(v / \mathrm{cm}^{-1}\right)$ : 3091 (Ar-CH), 2980 (aliphatic CH), 1680, 1650 $(2 \mathrm{C}=\mathrm{O}), 1576(\mathrm{C}=\mathrm{N}) 1492$ (deformation $\left.\mathrm{CH}_{2}\right), 1381(\mathrm{NCN}), 1225(\mathrm{C}-\mathrm{F}), 919,867$ and 815 (p-substituted phenyl). ${ }^{1} \mathrm{H}-\mathrm{NMR}$ (DMSO d 6 ) $\delta: 7.69$ - 7.29 (m, 8H, aromatic protons), 6.98 - 6.67 (d, d, s, H adjacent F), 3.65 $3.613\left(\mathrm{t}, 2 \mathrm{H}, \mathrm{CH}_{2}\right) .{ }^{13} \mathrm{C}-\mathrm{NMR}\left(\mathrm{DMSO} \mathrm{d}_{6}\right) \delta: 164.01,162.93,155,147.86,132.18,131.83-131.29,130.54$, 130.49, 115.03, 114.88, 77.97 - 77.54, 67.22 and 40.03-39.33. Anal. Calcd: C, 61.36; H, 2.84; N, 15.90; and F, $10.79 \%$; for $\mathrm{C}_{18} \mathrm{H}_{10} \mathrm{~N}_{4} \mathrm{~F}_{2} \mathrm{O}_{2}$ (324). Found: C, 61.86; H, 2.56; N, 15.78; and F, $10.58 \%$.

\subsubsection{4-Amino-2-oxo-7,8-di(4'-fluorophenyl)pyrimido[3,2-b][1,2,4-]triazine (6)}

A mixture of $1(0.01 \mathrm{~mol})$ and ethyl cyanoacetate $(0.01 \mathrm{~mol})$ in THF was refluxed for $4 \mathrm{~h}$. The solid obtained after cooling the reaction mixture was filtered and crystallized from ethanol to give deep-yellow crystals, yield 65\%, m.p. $198^{\circ} \mathrm{C}-200^{\circ} \mathrm{C}$. UV (EtOH): $\lambda_{\max } 346 \mathrm{~nm}$. IR $\left(v / \mathrm{cm}^{-1}\right)$ : $3300\left(\mathrm{NH}_{2}\right), 1670,1610$ (deformation $\mathrm{NH}_{2}$ ), 1229 (C-F), 828 and 810 (p-substituted ring). ${ }^{1} \mathrm{H}-\mathrm{NMR}$ (DMSO $\mathrm{d}_{6}$ ) $\delta: 7.40-7.29$ (m, 8H, aromatic protons), 6.971 (s, $1 \mathrm{H}$, =CH cyclic), $6.96-6.69$ (d, d, s, H adjacent of F), $3.62\left(\mathrm{~s}, 2 \mathrm{H}, \mathrm{NH}_{2}\right) .{ }^{13} \mathrm{C}-\mathrm{NMR}\left(\mathrm{DMSO} \mathrm{d}_{6}\right) \delta$ : 164.01, 154.9, 147.8, 132.16, 131.81 - 130.48, 115, 114.8, 77.78 - 77.57 and 67.21. M/S (Int. \%): 351 (8.18), 307 (28.13), 214 (100). Anal. Calcd: C, 61.53; H, 3.13; N, 19.94; and F, 10.82\%; for $\mathrm{C}_{18} \mathrm{H}_{11} \mathrm{~N}_{5} \mathrm{~F}_{2} \mathrm{O}$ (351). Found: C, 61.33; H, 3.02; N, 19.58; and F, 10.69\%.

\subsubsection{7,8-Di(4'-fluorophenyl)-3-(arylidene)pyrimido[3,2-b][1,2,4-]triazin-2,4-dione (5)}

A mixture of $4(0.01 \mathrm{~mol})$ and p-chlorobenzaldehyde $(0.01 \mathrm{~mol})$ in EtOH was refluxed for $1 \mathrm{~h}$ and then allowed to cool at room temperature. The solid thus obtained was filtered and crystallized from ethanol to give $\mathbf{5}$ as yellowish crystals, yield 78\%, m.p. $208^{\circ} \mathrm{C}-209^{\circ} \mathrm{C}$. IR $\left(v / \mathrm{cm}^{-1}\right)$ : 3024 (Ar-CH), 1680, 1660 (2C=O), 1610 (C=C), $1576(\mathrm{C}=\mathrm{N}), 1382(\mathrm{NCN}), 1227(\mathrm{C}-\mathrm{F}), 820$ and 815 (p-substituted ring). ${ }^{1} \mathrm{H}-\mathrm{NMR}$ (DMSO d 6 ) $\delta: 9.9$ (s, $1 \mathrm{H}$, $\mathrm{CH}=$ ), $7.76-7.75,7.70-7.60$ (m, 8H, aromatic protons), $7.35-7.20$ (m, 4H, aryl protons), and $6.95-6.37$ (d, d, s, $\mathrm{H}$ of adjacent F). Anal. Calcd: C, 63.15; H, 2.73; N, 11.78; F, 8.0; and Cl, 7.57\%; for $\mathrm{C}_{25} \mathrm{H}_{13} \mathrm{~N}_{4} \mathrm{~F}_{2} \mathrm{ClO}_{2}(475)$. Found: C, 62.88; H, 2.60; N, 11.58; F, 7.69; and Cl, 7.49\%.

\subsubsection{7,8-Di(4'-fluorophenyl)-4-arylidino-pyrimido[3,2-b][1,2,4-]triazin-2-one(7)}

A mixture of $6(0.01 \mathrm{~mol})$ and p-chlorobenzaldehyde $(0.01 \mathrm{~mol})$ in EtOH was refluxed for $1 \mathrm{~h}$ and subsequently left to cool at room temperature. A solid appeared which was filtered and crystallized from ethanol to give yellow crystals, yield 82\%, m.p. $212^{\circ} \mathrm{C}-214^{\circ} \mathrm{C}$. IR $\left(v / \mathrm{cm}^{-1}\right)$ : $3092(\mathrm{Ar}-\mathrm{CH}), 1668(\mathrm{C}=\mathrm{O}), 1602(\mathrm{C}=\mathrm{N}), 1226(\mathrm{C}-\mathrm{F})$, 919, 858 and 815 (p-substituted ring). ${ }^{1} \mathrm{H}$-NMR (DMSO $\mathrm{d}_{6}$ ) $\delta: 7.85-7.81$ (m, 4H, aromatic H), 7.40 - 7.28 (m, $8 \mathrm{H}$, aromatic H), 6.99 - 6.97 (d, d, s, H of adjacent F), $6.838(1 \mathrm{H}, \mathrm{CH}=\mathrm{N}) .{ }^{13} \mathrm{C}-\mathrm{NMR}\left(\mathrm{DMSO} \mathrm{d}_{6}\right) \delta: 163.96$, 161.24, 154.92, 147.68, 132.32, 131.95, 130.58 - 130.52, 115.03, 115.02, 114.89, 114.88, $78.25-77.81$ and 40.16. Anal. Calcd: C, 63.29; H, 2.95; N, 14.76; F, 8.01; and Cl, 7.59\%; for $\mathrm{C}_{25} \mathrm{H}_{14} \mathrm{~N}_{5} \mathrm{~F}_{2} \mathrm{ClO}$ (474). Found: C, 62.98; H, 2.75; N, 14.49; F, 7.78; and Cl, 7.38\%.

\subsubsection{Ethyl 3-(carboxyamino)-5,6-di(4'-fluorophenyl)-1,2,4-triazine (8)}

A mixture of $1(0.01 \mathrm{~mol})$ and ethyl chloromethanoate $(0.01 \mathrm{~mol})$ in benzene-TEA mixture was refluxed for an hour. The solid obtained after cooling the reaction mixture was filtered and crystallized from THF to give 8 as 
faint yellow crystals, yield 60\%, m.p. $178^{\circ} \mathrm{C}-180^{\circ} \mathrm{C}$. IR $\left(v / \mathrm{cm}^{-1}\right): 3300(\mathrm{NH}), 3080$ (Ar-CH), 2980 (R-CH), 1676 (C=O), 1483 (deformation $\mathrm{CH}_{3}$ ), 1381 (NCN), 1226 (C-F), 1010 (O-C-O), 840, and 815 (p-substituted ring). ${ }^{1} \mathrm{H}-\mathrm{NMR}$ (DMSO d $\left.\mathrm{d}_{6}\right) \delta: 8.87(\mathrm{~s}, 1 \mathrm{H}, \mathrm{NH}$ ), 7.68 - 7.40, 7.39 - 7.29 (each m, 8H, aromatic $\mathrm{H}$ ), 7.03 - 7.00, 6.94 - 6.82 (d, d, s, H adjacent F), $4.20\left(\mathrm{t}, 2 \mathrm{H}, \mathrm{CH}_{2} \mathrm{O}\right.$ ), and $1.4-1.2\left(\mathrm{~s}, 3 \mathrm{H}, \mathrm{CH}_{3}\right) .{ }^{13} \mathrm{C}-\mathrm{NMR}\left(\mathrm{DMSO} \mathrm{d}_{6}\right) \delta$ : $164.87,161.81,160.98,157.05,147.64,146.91,141.26$, 132.14, 132.08, 130.86 - 127.10, 115.40, 115.25, 114.96, 114.45, 78.46 - 78.03, 39.98, and 14.19. Anal. Calcd: C, 60.67; H, 3.93; N, 15.73 and F, 10.67\%; for $\mathrm{C}_{18} \mathrm{H}_{14} \mathrm{~N}_{4} \mathrm{~F}_{2} \mathrm{O}_{2}$ (356). Found: C, 60.41; H, 3.64; N, 15.61 and F, 10.55\%.

\subsubsection{N4-(5'-6'-diaryl-1,2,4-triazin-3'-yl)semicarbazide (10)}

A mixture of $8(0.01 \mathrm{~mol})$ and hydrazine hydrate $(0.01 \mathrm{~mol})$ in EtOH was refluxed for $2 \mathrm{~h}$, and then cooled at room temperature. The solid obtained was filtered and crystallized from ethanol to give $\mathbf{1 0}$ as faint yellow crystals, yield $60 \%$, m.p. $198^{\circ} \mathrm{C}-200^{\circ} \mathrm{C}$.

IR $\left(v, \mathrm{~cm}^{-1}\right)$ : 3334, $3269\left(\mathrm{NH}, \mathrm{NH}_{2}\right), 3092(\mathrm{Ar}-\mathrm{CH}), 1660(\mathrm{C}=\mathrm{O}), 1228$ (C-F), 860 and 810 (p-substituted ring). ${ }^{1} \mathrm{H}-\mathrm{NMR}$ (DMSo-d $\mathrm{d}_{6}$ ): 8.8 (s, 1H, NH), 7.72-7.25 (m, 8H aromatic H), 6.98 - 6.67 (m, d, d, s, H, adjacent F) and 3.16 (s, $2 \mathrm{H}, \mathrm{NH}_{2}$ ). ${ }^{13} \mathrm{C}-\mathrm{NMR}\left(\mathrm{DMSO}_{6}\right.$ ): 164.02, 161.29, 155.02, 147.86, 132.17, 131,82, 131.35, 131.29, 130.54 - 130.49, 115.13, 115.02, 114.88, 77.94 - 77.53 and 40.14 - 39.19. Analy. Calcd.: C, 56.14; H, 3.50; N, 24.26 and F, 11.11\%; for $\mathrm{C}_{16} \mathrm{H}_{12} \mathrm{~N}_{6} \mathrm{~F}_{2} \mathrm{O}$ (342). Found: C, 55.89; H, 3.35; N, 24.39; and F, $11.01 \%$.

\subsubsection{0. $\mathrm{N}^{4}$-(5'-6'-Di(4'-fluorophenyl)-1,2,4-triazin-3'-yl)thiosemicarbazide (11)}

A mixture of $1(0.01 \mathrm{~mol})$ and carbon disulfide $(0.01 \mathrm{~mol})$ in $1 \% \mathrm{KOH}$ solution was stirred for $2 \mathrm{~h}$ at room temperature to give the intermediate $\mathbf{9}$. Now a mixture of $\mathbf{9}(0.01 \mathrm{~mol})$ and hydrazine hydrate $(0.01 \mathrm{~mol})$ in EtOH was refluxed for $2 \mathrm{~h}$ and subsequently cooled in an ice-bath for few minutes to form a brownish yellow solid. The solid was filtered and crystallized from ethanol to give $\mathbf{1 1}$ as orange crystals, yield $78 \%$, m.p. $203^{\circ} \mathrm{C}-204^{\circ} \mathrm{C}$. IR $\left(v / \mathrm{cm}^{-1}\right)$ : 3314, 3229, 3192 (NH, NH, NH). $1381(\mathrm{NCN}), 1225$ (C-F), 1157 (C=S) and 850 (p-substituted ring). ${ }^{1} \mathrm{H}-\mathrm{NMR}$ (DMSO-d $\mathrm{d}_{6}$ ): 772 - 7.29 (m, 8H, aromatic H), 6.98 - 6.72 (m, d, d, s, H, adjacent F) and 3.14 (s, 2H, $\mathrm{NH}_{2}$ ). ${ }^{13}$ C-NMR (DMSO-d $\mathrm{d}_{6}$ : 164.0, 162.2, 161.28, 154.98, 147.81, 132.21, 131.85 - 130.50, 115.03, 114.88, 78.04 - 77.61 and 40.02-39.19. Analy. Calcd: C, 53.63; H, 3.35; N, 23.46; and F, 10.61; S, 8.93\%, for $\mathrm{C}_{16} \mathrm{H}_{12} \mathrm{~N}_{6} \mathrm{~F}_{2} \mathrm{~S}$ (358), Found: C, 53.38; H, 3.20; N, 23.41; and F, 10.38; S, 8.78\%.

\subsubsection{5,6-Di(4'-fluorophenyl)-3-(2',3'-dihydro-3'-oxo-1',2',4'-triazol-4'-yl)-1,2,4-triazine (12)}

A mixture of $10(0.5 \mathrm{~g})$ and triethyl orthoformate $(10 \mathrm{ml})$ was refluxed for $2 \mathrm{~h}$ and then cooled at room temperature. The produced solid was filtered and crystallized from dioxan to give $\mathbf{1 2}$ as faint yellowish crystals, yield 65\%, m.p. $190^{\circ} \mathrm{C}-192^{\circ} \mathrm{C}$. IR $\left(\mathrm{v} / \mathrm{cm}^{-1}\right)$ : $3192(\mathrm{NH}), 1679(\mathrm{C}=\mathrm{O}), 1572(\mathrm{C}=\mathrm{N}), 1382(\mathrm{NCN}), 1227(\mathrm{C}-\mathrm{F}), 880$ and 816 (p-substituted ring). ${ }^{1} \mathrm{H}-\mathrm{NMR}$ (DMSO-d $\mathrm{d}_{6}$ ): 8.81 (s, 1H, NH), 7.62 - 7.27 (m, 8H, aromatic H), 6.966 - 6.92 (d, d, s, H, adjacent F) and $6.60(\mathrm{~s}, 1 \mathrm{H}, \mathrm{CH}=\mathrm{N}):{ }^{13} \mathrm{CNMR}\left(\mathrm{DMSO}-\mathrm{d}_{6}\right): 164.02,161.40,154.9,132.16,131.28$, 130.53 - 130.48, 115.02, 114.88 and 77.93 - 77.49. Analy. Calcd: C, 57.95; H, 2.84; N, 23.86; and F.10.79\%, for $\mathrm{C}_{17} \mathrm{H}_{10} \mathrm{~F}_{2} \mathrm{O}$ (352). Found: C, 57.55; H, 2.70; N, 23.59; and F, 10.61\%.

\subsubsection{5,6-Di(4'-fluorophenyl)-3-(3'-mercapto-5'-hydroxy-1',2',4'-triazol-4'-yl)-1,2,4-triazine (13)}

A mixture of $11(0.01 \mathrm{~mol})$ and carbon disulfide $(0.01 \mathrm{~mol})$ in dimethyl formamide was refluxed for $2 \mathrm{~h}$. The reaction mixture was cooled in ice-bath to form a solid which was filtered and crystallized from ethanol to give 13 as orange crystals, yield $65 \%$, m.p. $210^{\circ} \mathrm{C}-212^{\circ} \mathrm{C}$. IR $\left(v / \mathrm{cm}^{-1}\right)$ : 3259, $3192(\mathrm{NH}, \mathrm{NH}), 1658(\mathrm{C}=\mathrm{O}), 1389$ (NCN), 1225 (C-F), 1156 (C=S), 880 and 829 (p-substituted ring). ${ }^{1} \mathrm{H}-\mathrm{NMR}$ (DMSO-d $\mathrm{d}_{6}$ ): 13.3, 12.8 (each s, NH, $\mathrm{NH}), 7.91-7.28\left(\mathrm{~m}, 8 \mathrm{H}\right.$, aromatic H) and $6.98-6.69\left(\mathrm{~m}, \mathrm{~d}, \mathrm{~d}, \mathrm{~s}, \mathrm{H}\right.$ adjacent F). ${ }^{13} \mathrm{CNMR}$ (DMSO-d $\left.\mathrm{d}_{6}\right): 195$ (164.0), 161.28, 154.99, 147.83, 132.20 131.84, 131.29 - 130.49, 115.03, 114.88 and 78.01 - 77.58. Analy. Calcd: C, 53.12; H, 2.60; N, 21.87: F. 9.89; and S, 8.33\%, for $\mathrm{C}_{17} \mathrm{H}_{10} \mathrm{~N}_{2} \mathrm{SO}$ (384), Found: C, 52.89; H, 2.39; N, 21.55; F, 9.69; and S, 8.01\%.

\subsubsection{5,6-Di(4'-fluorophenyl)-3-(6'-methyl-3'-hydroxy-5'-oxo-1',2',4'-triazin-4'-yl)-1,2,4-triazine}

Equimolar mixture of $\mathbf{1 0}$ and sodium pyruvate in $5 \% \mathrm{NaOH}$ solution $(50 \mathrm{ml})$ was refluxed for $2 \mathrm{~h}$, cooled then poured onto ice-HCl. The solid obtained was filtered and crystallized from ethanol to give $\mathbf{1 4}$ as faint yellow crystals, yield $65 \%$, m.p. $213^{\circ} \mathrm{C}-214^{\circ} \mathrm{C}$. IR $\left(v / \mathrm{cm}^{-1}\right)$ : 3372, $3297(\mathrm{OH}+\mathrm{NH}), 1700,1626(\mathrm{CO}, \mathrm{CONH}), 1567$ 
$(\mathrm{C}=\mathrm{N}), 1483$ (deformation $\left.\mathrm{CH}_{3}\right) 1379(\mathrm{NCN}), 1224(\mathrm{C}-\mathrm{F}), 1155$ (C=S), 829 and 810 (p-substituted ring). ${ }^{1} \mathrm{H}-\mathrm{NMR}$ (DMSO-d $\mathrm{d}_{6}$ ): 13.481 (s, $\left.1 \mathrm{H}, \mathrm{NH}\right), 7.65,7.41,7.39,7.22,7.20,7.19,6.985,6.978$ (8H, aromatic H), 6.971 - 6.964, $6.957-6.950$ (m, d, d, s, H of F) and $1.903\left(\mathrm{~s}, 3 \mathrm{H}, \mathrm{CH}_{3}\right) .{ }^{13} \mathrm{C}-\mathrm{NMR}\left(\mathrm{DMSO}-\mathrm{d}_{6}\right)$ : 195.63, 164.73, 163.06, 161.66, 153.43, 140.91, 131.69, 131.11, 131.09 - 129.99, 115.21, 115.06, 114.95, 77.88 - 77.44, 40.02, and 39.19. Analy. Calcd: C, 57.86; H, 3.04; N, 12.13; and F, 9.64\%, for $\mathrm{C}_{19} \mathrm{H}_{12} \mathrm{~N}_{6} \mathrm{~F}_{2} \mathrm{O}_{2}$ (394). Found: C, 57.49; H, 2.89; N, 21.01; and F, 9.33\%.

\subsubsection{5,6-Di(4'-fluorophenyl)-3-(3'-mercapto-1,2,4-triazol-4'-yl)-1,2,4-triazine (15)}

A mixture of $11(0.01 \mathrm{~mol})$ and triethyl orthoformate $(0.01 \mathrm{~mol})$ was refluxed for $2 \mathrm{~h}$ and then cooled at room temperature. The solid obtained was filtered and crystallized from dioxan to give $\mathbf{1 5}$ as yellow crystals, yield 72\%, m.p. $183^{\circ} \mathrm{C}-184^{\circ} \mathrm{C}$. IR ( $\left.v / \mathrm{cm}^{-}{ }^{1}\right)$ : 3298, $3191(\mathrm{NH}), 1610,1576(\mathrm{C}=\mathrm{N}), 1381$ (NCN), 1225 (C-F), 1157 $(\mathrm{C}=\mathrm{S}), 840$ and 810 (p-substituted ring). ${ }^{1} \mathrm{H}-\mathrm{NMR}\left(\mathrm{DMSO}_{-} \mathrm{d}_{6}\right.$ ): 10.03 (S, 1H, NH=S), $7.60-511,7.48-7.27$ and 7.0 - 6.55 (m, 9H, aromatic H). Analy. Calcd: C, 55.43; H, 2.71; N, 22.82; F.10.32 and S, 8.69\%, for $\mathrm{C}_{17} \mathrm{H}_{10} \mathrm{~N}_{6} \mathrm{~F}_{2} \mathrm{~S}$ (368). Found: C, 55.21; H, 2.33; N, 22.55; F.10.01 and S, 8.49\%.

\subsubsection{5,6-Di(4'-fluorophenyl)-3-(3',5'-dimercapto-1',2',4'-triazol-4'-yl)-1,2,4-triazine (16)}

A mixture of $11(0.01 \mathrm{~mol})$ and carbon disulfide $(0.01 \mathrm{~mol})$ in DMF was refluxed for $2 \mathrm{~h}$ and then cooled at room temperature. The solid obtained was filtered and crystallized from methanol to give 16 as orange crystals, yield 80\%, m.p. $203^{\circ} \mathrm{C}-204^{\circ} \mathrm{C}$. IR ( $\left./ \mathrm{cm}^{-1}\right)$ : $3197(\mathrm{NH}), 3150(\mathrm{NH}), 1595(\mathrm{C}=\mathrm{N}), 1564(\mathrm{C}=\mathrm{N}), 1382(\mathrm{NCN}), 1224$ (C-F), 1151(C=S), 831 and 810 (p-substituted ring). ${ }^{13} \mathrm{C}-\mathrm{NMR}$ (DMSO-d $\mathrm{d}_{6}$ ): 163.99، ،162.90 161.47، 161.26 ، 154.96، 147 ، 132.25 ، 132.23 ، 131.89 ، 131.87131 .31 ، 130.56 ، 130.50 ، ، 115.02114 .88 ، 77 and 77.69-78.12. Analy. Calcd: C, 51.0; H, 2.50; N, 21.0; F, 9.5; and S, 16.0\%, for $\mathrm{C}_{17} \mathrm{H}_{10} \mathrm{~N}_{6} \mathrm{~F}_{2} \mathrm{~S}_{2}$ (400). Found: C, 50.85; H, 2.31; N, 20.88; F, 9.33; and S.15.79\%.

\subsubsection{5,6-Diaryl-3-(6'-methyl-3'-mercapto-6'-oxo-1',2',4'-triazin-4'-yl)-1,2,4-triazine (17)}

A mixture of $11(0.01 \mathrm{~mol})$ and sodium pyruvate $(0.01 \mathrm{~mol})$ in $5 \% \mathrm{NaOH}$ aq. $(20 \mathrm{ml})$ was refluxed for $3 \mathrm{~h}$. The reaction mixture was cooled and then poured on ice cold $\mathrm{HCl}$ solution. The solid obtained was filtered and crystallized from ethanol to give $\mathbf{1 7}$ as yellow crystals, yield 60\%, m.p. 220-222 ${ }^{\circ} \mathrm{C}$. IR $\left(v / \mathrm{cm}^{-1}\right): 3197(\mathrm{NH}), 2906$, 2855 $\left(\mathrm{CH}_{3}\right), 1666(\mathrm{C}=\mathrm{C}), 1586(\mathrm{C}=\mathrm{N}), 1472$ (deformation $\left.\mathrm{CH}_{3}\right), 1367(\mathrm{NCN}), 1224(\mathrm{C}-\mathrm{F}), 1158(\mathrm{C}=\mathrm{S}), 872$ and 792 (p-substituted ring). ${ }^{1} \mathrm{H}-\mathrm{NMR}\left(\mathrm{DMSO}_{\mathrm{d}}\right.$ ): 11.86 (S, 1H, NH), 7.75 - 7.38, 7.30 - 7.28 (each, m, 8H, aromatic H), 6.97 - 6.69 (d, d, s, H-CF), and 1.08 (S, 3H, $\left.\mathrm{CH}_{3}\right) .{ }^{13} \mathrm{C}-\mathrm{NMR}$ (DMSO-d $\mathrm{d}_{6}$ ): 180, 163.98, 162.91, 161.27, 154.96, 147.84, 132.21, 131.85, 131.36, 131.30, 130.55 - 130.02, 115.02, 114.88, 78.03 - 77.60 and 39.20. Analy. Calcd: C, 55.60; H, 2.92; N, 20.48; F, 9.26; and S.7.80\%, for $\mathrm{C}_{19} \mathrm{H}_{12} \mathrm{~N}_{6} \mathrm{~F}_{2} \mathrm{SO}$ (410). Found: C, 55.39; H, 2.80; N, 20.29; F.9.01 and S, 7.55\%.

\subsubsection{N,N'-[5,6-di(4'fluorophenyl)-1,2,4-triazin-3'-yl] thiourea (18)}

Equimolar amount of compounds $\mathbf{1}$ and $\mathbf{9}$ in ethanol $(50 \mathrm{ml}$ ) was refluxed for $2 \mathrm{~h}$. The reaction mixture was cooled in an ice bath to form a solid which was filtered and crystallized from ethanol to give $\mathbf{1 8}$ as faint yellow crystals, yield 65\%, m.p. $193^{\circ} \mathrm{C}-194^{\circ} \mathrm{C}$. IR $\left(v, \mathrm{~cm}^{-1}\right)$ : 3300, 3289, 3192 (C-F), 1157(C=S), 827 and 814 (psubstituted ring). Analy. Calcd: C, 60.98; H, 2.95; N, 18.36; F, 12.45; and S.5.24\%, for $\mathrm{C}_{31} \mathrm{H}_{18} \mathrm{~N}_{8} \mathrm{~F}_{4} \mathrm{~S}(610)$. Found: C, 60.65; N, 2.80; F, 12.13; and S, 5.00\%.

\subsubsection{N,N'-Di[di(4'-fluorophenyl)1,2,4-triazin-3-yl]-thiobarbituric Acid (19)}

A mixture of $18(0.01 \mathrm{~mol})$ and malonic acid $(0.01 \mathrm{~mol})$ in glacial acetic acid $(50 \mathrm{ml})$ was refluxed for $4 \mathrm{~h}$. The reaction mixture was cooled and then poured onto ice. The solid obtained was filtered and crystallized from ethanol to give 19 as yellow crystals, yield $60 \%$, m.p. $300^{\circ} \mathrm{C}-302^{\circ} \mathrm{C}$. UV (Ethanol): $\lambda_{\max } 334 \mathrm{~nm}$. IR $\left(v / \mathrm{cm}^{-1}\right)$ : 2980, 2868 (aliphatic CH), $1663(\mathrm{C}=\mathrm{O}), 1595,1561(\mathrm{C}=\mathrm{N}), 1366(\mathrm{NCN}), 1223(\mathrm{C}-\mathrm{F}), 1156(\mathrm{C}=\mathrm{S}), 854$ and 820 (p-substituted ring). ${ }^{1} \mathrm{H}-\mathrm{NMR}$ (DMSO-d ${ }_{6}$ ): 13.52 (s. IH, OH), 7.82 - 7.00 (m, 16H, aromatic H), 6.98, 6.97, 6.85(d, d, S, H, of C-F) and 2.499 (S, CH CH. $^{13} \mathrm{C}-\mathrm{NMR}\left(\mathrm{DMSO}_{6} \mathrm{~d}_{6}\right): 180,165.68,164.65,163.27,162.98,161.62$, 154.93, 140.95, 131.95 - 130.14, 115.22, 114.89, 78.28 - 77.85 and 24.88. Analy. Calcd: C, 60.15; H, 2.66; N, 16.49; F, 11.10; and S, 4.55\%. for $\mathrm{C}_{34} \mathrm{H}_{18} \mathrm{~N}_{8} \mathrm{~F}_{4} \mathrm{SO}_{2}$ (678). Found: C, 59.89; H, 2.51; N, 16.30; F, 10.89; and S, $4.40 \%$. 


\subsubsection{N,N'-Di[di(4'-fluorophenyl)1,2,4-triazin-3-yl]-5-arylidene-thiobarbituric Acid (20)}

Equimolar quantity of 19 and 4-chlorobenzaldehyde in ethanol $(50 \mathrm{ml})$, piperidine $(0.5 \mathrm{ml})$ was refluxed for $6 \mathrm{~h}$. The reaction mixture was cooled and neutralized with few drops of acetic acid. The solid precipitated was filtered and crystallized from ethanol to give 20 as yellow crystals, yield $60 \%$, m.p. $310^{\circ} \mathrm{C}-312^{\circ} \mathrm{C}$. UV (EtOH): $\lambda_{\max } 346 \mathrm{~nm}$. IR $\left(v, \mathrm{~cm}^{-1}\right): 3080$ (aromatic CH), 2920, (aliphatic CH), 1710, 1680(2C=O), 1385 (NCSN), 1250 (C-F), 1190 (C-S), 880 and 810 (p-substituted ring). ${ }^{1} \mathrm{H}-\mathrm{NMR}$ (DMSO-d 6 ): 7.66 - 7.64, 7.38 - 7.36, 7.29 - 7.27, (each, $\mathrm{m}, 21 \mathrm{H}$, aromatic $\mathrm{H}), 6.61,6.96$ and 6.92 , $\left(\mathrm{CH}=\right.$, d, d, s, of $\mathrm{H}$ adjacent to the $\mathrm{F}$ atoms). ${ }^{13} \mathrm{C}-\mathrm{NMR}$ (DMSO-d6): 180, 164, 162.94, 162.36, 161.30, 155.02, 147.89, 132.14, 131.79, 131.34, 131.28, 130.53, 130.48, 115.03, 114.88, 77.90 - 77.47, 66.42 and 40.12 - 39.17. Analy. Calcd: C, 61.42; H, 2.62; N, 13.48; F, 9.48, Cl, 4.49; and S, 3.99\%, for $\mathrm{C}_{41} \mathrm{H}_{21} \mathrm{~N}_{8} \mathrm{FClSO}_{2}$ (801). Found: C, 61.01; H, 2.55; N, 12.98; F, 9.03; Cl. 3.99 and S, $3.55 \%$.

\section{Results and Discussion}

\subsection{Chemistry}

3-Amino-1,2,4-triazines are important intermediates in the synthesis of heterobicylic systems. Also, 5,6-diphenyl-1,2,4-triazine containing functional groups at position-3, especially amino and/or hydrazine groups, are used as nucleophilic reagents (electron donors) towards $\pi$-acceptors carbonitriles [25]. In addition, in most of these reactions, DMF is used as a strong polar aprotic solvent which accelerates the $\mathrm{SN}^{2}$ reactions [26].

Nucleophilic attack on exo $\mathrm{C}=\mathrm{N}$ bonds of 1,2,4-trizaine provides a direct and convenient method for functionalization of 1,2,4-triazines, which makes it possible to introduce various substituents in a single reaction. Thus, it is quite probable that their reactions with bifunctional nucleophiles would result in polycyclic compounds via attack by the second nucleophilic center at another carbon atom of hetero-ring [26].

The presence of hetero atoms results in significant changes in the cyclic molecular structure, due to the availability of unshared pairs of electrons on nitrogen atoms and the difference in electronegativity between heteroatoms and carbons within the closed system.

The starting material 3-amino5,6-di(4'-fluorophenyl)-1,2,4-triazine (1) was prepared from refluxing amino-guanidine bicarbonate with 4,4'-difluorobenzil in n-ButOH [27] (Scheme 1). Structure of compound 1 was deduced from elemental analysis and spectral data. IR spectrum showed an absorption bands at $3200,1620 \mathrm{~cm}^{-1}$ for $\mathrm{NH}_{2}$ group, and $1250 \mathrm{~cm}^{-1}$ for C-F. ${ }^{1} \mathrm{H}-\mathrm{NMR}$ (DMSO-d $\mathrm{d}_{6}$ ) recorded $\delta$ at 2.89-1 (br, s, $2 \mathrm{H}, \mathrm{NH}_{2}$ ), 7.31 - 7.34, 7.39 - $7.44 \mathrm{ppm}$ for 8 aromatic protons with $\delta$ at 7.0-6.61 ppm as a characteristic doublet and a signal for the adjacent $\mathrm{H}$ to the $\mathrm{F}$ atom. ${ }^{13} \mathrm{C}-\mathrm{NMR}$ spectrum exhibited a resonance signals for carbons at $\delta 127.7-129.8$ for aromatic carbons and four other peaks at $\delta 136,148,156$, and $161 \mathrm{ppm}$ for C=N, C-N, C-F and C- $\mathrm{NH}_{2}$ respectively.

$\mathrm{X}$-ray analysis of 1,2,4-triazine ring reveal that the ring is slightly distorted due to the asymmetry induced by the electronegativity of nitrogen atoms and two intermolecular hydrogen bonds that stabilized the 1,2,4-triazine structure [28].

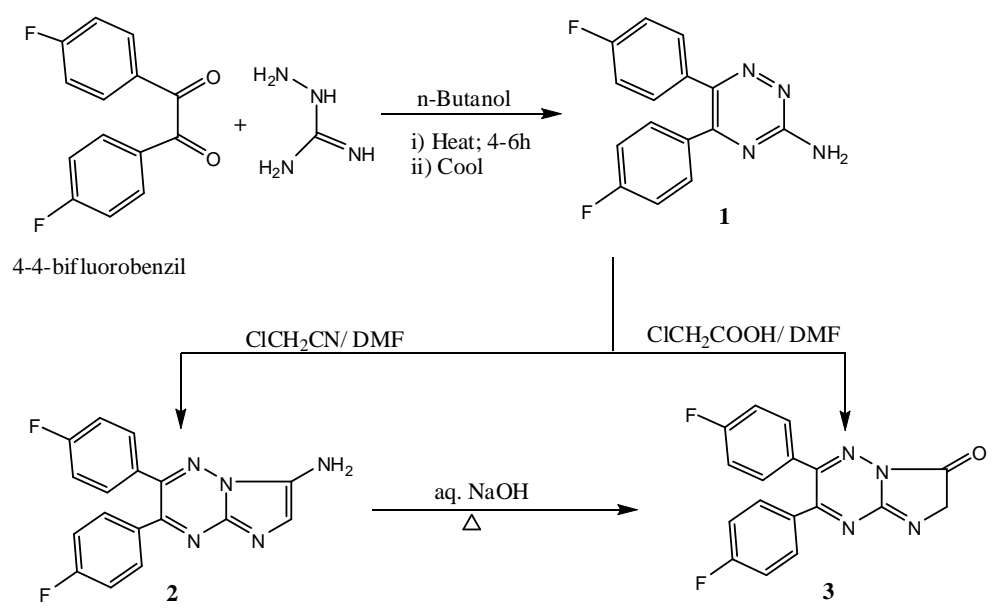

Scheme 1. Synthesis of 2 and 3. 
The ring closure of 3-amino-5,6-di(4'-fluorophenyl)-1,2,4-triazine (1) with chloroacetonitrile in boiling DMF produced 3-amino-6,7-di(4'-fluorophenyl)imidazolo[3,2-b][1,2,4]triazine (2), while reaction of 1 with monochloro acetic acid in refluxing DMF yielded 2,3-dihydro-6,7-diaryl-imidazolo[3,2-b][1,2,4]triazin-3-one (3). Moreover, compound 3 was also obtained via basic hydrolysis of 2 by warming in aqueous $\mathrm{NaOH}$.

Structure of compound 2 showed a characteristic bands at 3350 and $1623 \mathrm{~cm}^{-1}$ attributed to $\mathrm{NH}_{2}$ group while that of compound 4 had a characteristic band at $1660 \mathrm{~cm}^{-1}$ for $\mathrm{C}=\mathrm{O}$, in addition to bands at 2950 and $1480 \mathrm{~cm}^{-1}$ for $\mathrm{CH}_{2}$ group and an additional absorption at $1226 \mathrm{~cm}^{-1}$ for C-F. Mass spectra of 3 showed a molecular ion peak at $\mathrm{m} / \mathrm{z} 323$, with a base peak at $\mathrm{m} / \mathrm{z} 214$ for 4,4'-difluorophenyl acetylene radical [29].

Ring closure reactions of compound $\mathbf{1}$ with diethyl malonate and/or ethyl cyanoacetate in refluxing THF afforded 1,2,3,4-tetrahydro-7,8-di(4'-fluorophenyl)-pyrimido[3,2-b][1,2,4]traizin-2,4-dione (4) and 4-amino-7, 8-di(4'-fluorophenyl)-pyrimido[3,2-b][1,2,4]traizin-2-one (6), respectively. The condensation of both 4 and 6 with aromatic aldehyde in boiling ethanol-piperidine gave the arylidene $\mathbf{5}$ and the Schiff base $\mathbf{7}$ (Scheme 2).

Structures of both compounds $\mathbf{4}$ and $\mathbf{6}$ were elucidated from their analytical and spectral data. IR spectrum of 4 showed absorption bands at 1680 and $1650 \mathrm{~cm}^{-1}$ for the two $\mathrm{C}=\mathrm{O}$ groups, while that of 6 recorded absorption bands at $3300,1670 \mathrm{~cm}^{-1}$ due to $\mathrm{NH}_{2}$ and $\mathrm{C}=\mathrm{O}$ groups, respectively. Mass spectrum of 6 recorded a molecular ion peak at $351 \mathrm{~m} / \mathrm{z}$ and a base peak at $214 \mathrm{~m} / \mathrm{z}$. UV absorption spectrum of 5 showed a higher maximum $\left(\lambda_{\max }=\right.$ $351 \mathrm{~nm})$ than that of $4\left(\lambda_{\max }=346 \mathrm{~nm}\right)$, due to the extended conjugation in the heterocyclic ring in the former. ${ }^{1} \mathrm{H}-\mathrm{NMR}$ of 5 showed a prominent peak at $\delta 8.2 \mathrm{ppm}$ due to $\mathrm{C}=\mathrm{CH}$ Ar. ${ }^{13} \mathrm{C}-\mathrm{NMR}$ of compound $\mathbf{7}$ showed the resonance signal of exo $\mathrm{N}=\mathrm{CH}$ in addition to an endo $\mathrm{N}=\mathrm{C}$ of 1,2,4-triazine.

The treatment of compound $\mathbf{1}$ with ethyl chloroformate in benzene and triethylamine and/or $\mathrm{CS}_{2} / \mathrm{KOH}$ led to the formation of ethyl carboxylate $\mathbf{8}$ and the intermediate $\mathbf{9}$, respectively. Hydrazinolysis of $\mathbf{8}$ and $\mathbf{9}$ by refluxing with hydrazine hydrate in ethanol afforded $\mathrm{N}^{4}$-substituted semicarbazide/thiosemicarbazide $\mathbf{1 0}$ and $\mathbf{1 1}$, respectively (Scheme 3). IR spectra of both compounds $\mathbf{1 0}$ and $\mathbf{1 1}$ showed $\mathrm{C}=\mathrm{O}$ and $\mathrm{C}=\mathrm{S}$ at $3400,3100 \mathrm{~cm}^{-1}$ for $\mathrm{NH}$, $\mathrm{NH}_{2}$ groups, respectively.

Ring closure reactions of compound $\mathbf{1 0}$ with triethylorthoformate, carbondisulfide, dimethylformamide and/or sodium pyruvate ( $\mathrm{NaOH}$ solution) led to the direct formation of 3-(2',3'- dihydro-3'-oxo-1,2,4-triazol-4'- yl)-5,6di(4'-fluorophenyl)-1,2,4-triazine(12), 3-(3'-oxo-1,2,3,4-tetrahydro-5'-thioxo-1,2,4-triazol-4'-yl)-5,6-di-(4'-fluorophenyl)-1,2,4-triazine (13) and 3-(3',4'-dihydro-3',5'-dioxo-6'-methyl-1',2',4'-triazin-3'-yl)-5,6-di (4'-fluorophenyl)-1,2,4-triazine (14) (Scheme 4).

IR spectra of 12 and $\mathbf{1 4}$ evealed absorption bands at $3150-3100$ and $1680-1660 \mathrm{~cm}^{-1}$ for $\mathrm{NH}$ and $\mathrm{C}=\mathrm{O}$ groups, respectively. ${ }^{1} \mathrm{H}-\mathrm{NMR}$ spectrum of $\mathbf{1 4}$ showed resonance signals at $\delta 1.95,13.48$ and 8-6.6 ppm for $\mathrm{CH}_{3}$, $\mathrm{NH}$ and aromatic protons respectively. However compound $\mathbf{1 3}$ recorded a resonance $\mathrm{C}=\mathrm{S}$ at $\delta 195 \mathrm{ppm}$. Mass spectra of 13 exhibit a molecular ion peak at m/z 384 and a base peak at m/z 214 due to 4,4'-difluorophenyl acetylene radical [29].

Under the same experimental conditions, ring closure reactions of compound $\mathbf{1 1}$ with triethylorthoformate, carbondisulfide and sodium pyruvate resulted in 3-(2',3'- dihydro-3'-thioxo-1',2',4'-triazol-4'-yl)-5,6-di(4'-fluo-

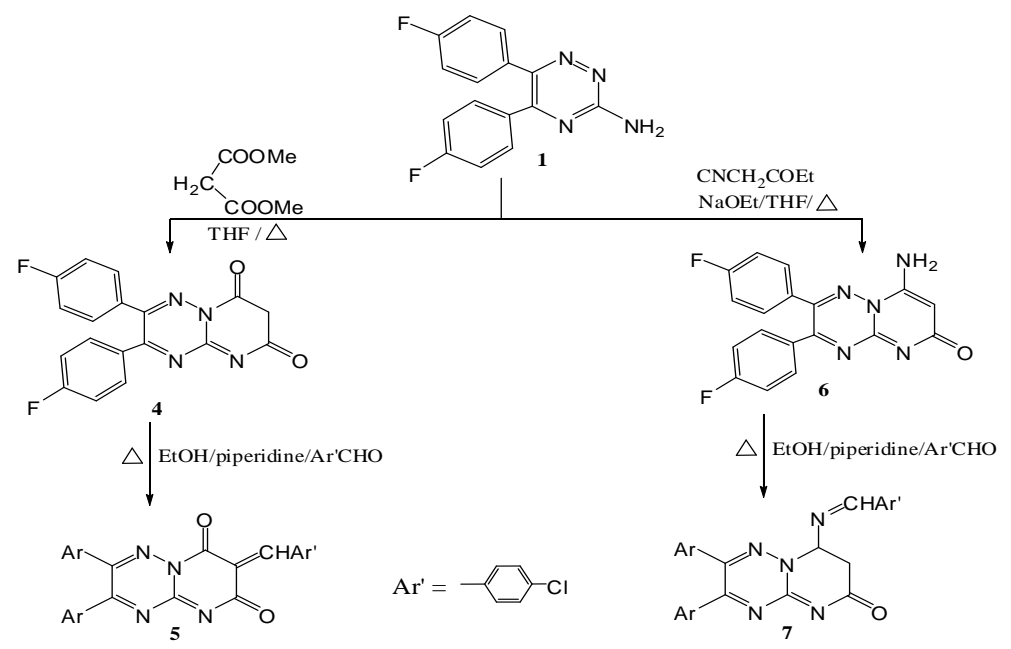

Scheme 2. Synthesis of 5 and 7. 


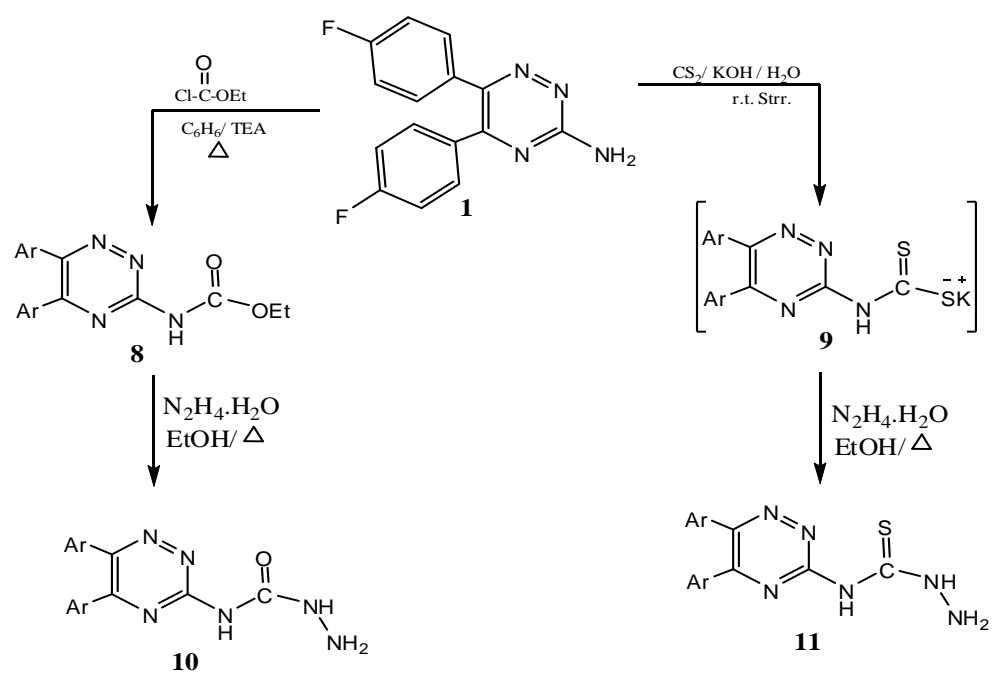

Scheme 3. Synthesis of $\mathbf{1 0}$ and $\mathbf{1 1 .}$

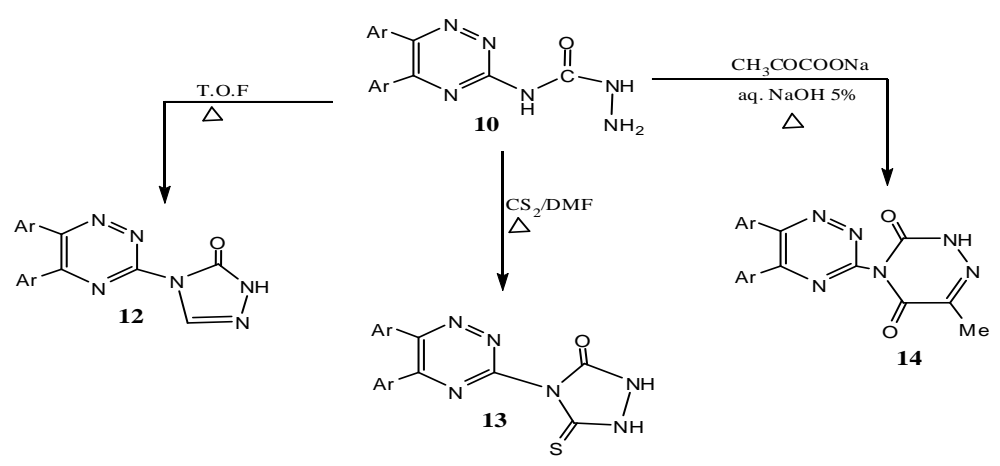

Scheme 4. Synthesis of 12-14.

rophenyl)-1,2,4-triazine (15), 3-(1',2',3',4'-tetrahydro-3',5'-thioxo-1',2',4'-triazol-4'-yl)-5,6-di(4'-fluorophenyl)1,2,4-triazine (16) and 3-(3',4'-dihydro-3'-thioxo-6-methyl-5'-oxo-1,2,4-triazol-4'-yl)-5,6-di(4'-fluorophenyl)1,2,4-triazine (17), respectively (Scheme 5). IR spectra of compounds 15-17 showed an absorption bands at 3200-3100 and 1180-1150 $\mathrm{cm}^{-1}$ for $\mathrm{NH}$ and $\mathrm{C}=\mathrm{S}$ groups, respectively. ${ }^{1} \mathrm{H}-\mathrm{NMR}$ of $\mathbf{1 7}$ recorded resonance signals at 1.08 and $11.85 \mathrm{ppm}$ for $\mathrm{CH}_{3}$ and $\mathrm{NH}$ protons, respectively. Also, ${ }^{13} \mathrm{C}-\mathrm{NMR}$ exhibited resonances for $\mathrm{C}=\mathrm{S}$, $\mathrm{C}=\mathrm{O}, \mathrm{C}=\mathrm{N}$ and $\mathrm{CH}_{3}$ at $\delta 180,163$ and $130 \mathrm{ppm}$ respectively.

Fluorinated N,N-disubstituted-thiobarbituric acid $\mathbf{1 9}$ was prepared from refluxing compound $\mathbf{9}$ with $\mathbf{1}$ in ethanol to give N,N-disubstituted-thiourea 18. Ring closure reaction of $\mathbf{1 8}$ with malonic acid on warming with glacial acetic acid yielded compound 19 (Scheme 6). IR spectra of compound 18 showed absorption bands at $3300-3190 \mathrm{~cm}^{-1}$ for $\mathrm{NH}, \mathrm{NH}$ of thiourea derivative which was not found in compounds 19 and $20 .{ }^{1} \mathrm{H}-\mathrm{NMR}$ spectrum of compound 19 recorded a resonance signal at $\delta 2.44 \mathrm{ppm}$ for $\mathrm{CH}_{2}$ protons. Also, ${ }^{13} \mathrm{C}-\mathrm{NMR}$ showed a signal at $\delta 24.88 \mathrm{ppm}$ for aliphatic carbons. IR spectrum of 20 showed absorption bands at 1680, 1660 and 1611 $\mathrm{cm}^{-1}$ for the two $\mathrm{C}=\mathrm{O}$ and $\mathrm{CH}=\mathrm{C}$ groups, in addition to two bands at 1255 and $1185 \mathrm{~cm}^{-1}$ for $\mathrm{C}-\mathrm{F}$ and $\mathrm{C}=\mathrm{S}$ groups, respectively. ${ }^{13} \mathrm{C}-\mathrm{NMR}$ of $\mathbf{2 0}$ exhibited resonance signals at $\delta 188,166$ and $39.48 \mathrm{ppm}$ attributed to $\mathrm{C}=\mathrm{S}$, $\mathrm{C}=\mathrm{O}$ and $\mathrm{CH}=\mathrm{C}$ carbons, respectively. It is interesting to note that $\mathrm{UV}$ absorption of compound 20 recorded $\lambda_{\max }$ at $334 \mathrm{~nm}$ which is higher than the value for compound $19\left(\lambda_{\max }=332\right)$, confirming ta presence of an $\alpha$, $\beta$-unsaturated cyclic ketone system in the former.

\subsection{Biological Evaluation}

The CDK2 inhibitory activity of the synthesized compounds revealed that eleven out of the tested twenty compounds displayed variable inhibitory effects. However compounds 11, 13, 16 and 17 showed profound activity. 


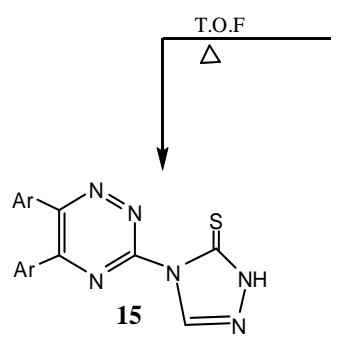

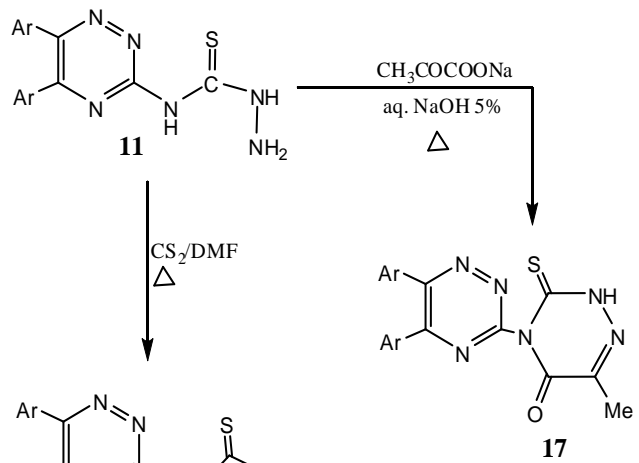

16

Scheme 5. Synthesis of $\mathbf{1 5}$ and $\mathbf{1 7 .}$<smiles>Nc1nnc(-c2ccc(F)cc2)c(-c2ccc(F)cc2)n1</smiles>

1

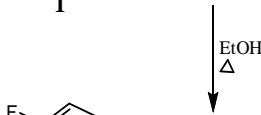<smiles>Fc1ccc(-c2nnc(NC(=S)Nc3nnc(-c4ccc(F)cc4)c(-c4ccc(F)cc4)n3)nc2-c2ccc(F)cc2)cc1</smiles>

9
$\mathrm{H}_{2}(\mathrm{COOH}) / \mathrm{AcOH} / \Delta$

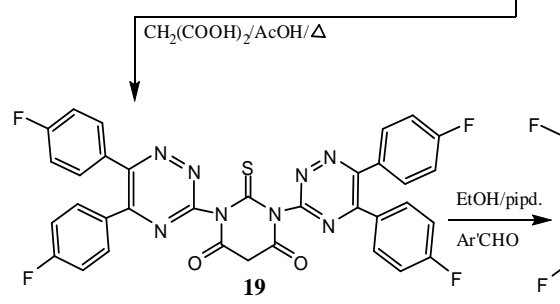

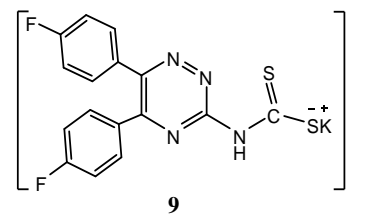<smiles>O=C1C(=C[Al])C(=O)N(c2nnc(-c3ccc(F)cc3)c(-c3ccc(F)cc3)n2)C(=S)N1c1nnc(-c2ccc(F)cc2)c(-c2ccc(F)cc2)n1</smiles>

Scheme 6. Synthesis of 18-20.

Compound $\mathbf{1 6}$ was found to be equipotent to the positive reference Olomoucine.

Further examination of the structures of the active compounds revealed that all of them have almost similar $\mathbf{N}$-(amino(hydrazinyl)methyl)hydrazinecarbothioamide scaffolding as displayed in Figure 1 by bold bonds . Though these structural features are present in other active compounds but other molecular framework variants rends them less active and less sensitive towards the CDK2 enzyme. Also, the presence of mercapto-groups in fluorinated heterobicyclic nitrogen systems $(\mathbf{1 1}, \mathbf{1 3}, \mathbf{1 6}, \mathbf{1 7})$ exhibited good effects toward cell damage (Table 1).

However, in vitro anti-tumor testing of the highly active compounds $(\mathbf{1 1}, \mathbf{1 3}, \mathbf{1 6}, \mathbf{1 7})$ were evaluated according to the described method, under different concentrations, a sulforhodamine B (SRB) protein assay was used to estimate cell viability or growth by determining $\mathrm{GI}_{50}$, TGI and $\mathrm{LC}_{50}$ (Table 2).

The results obtained, indicated that all the tested compounds were effective towards some types of tumors. Compound 11 was active against non-small cell lung cancer, renal cancer and breast cancer cell lines, while compound $\mathbf{1 3}$ had activity towards leukemia, renal cancer, non-small cell lung cancer and breast cancer. Furthermore, compounds $\mathbf{1 6}$ and $\mathbf{1 7}$ exhibited significant degrees of activity towards non-small cell lung cancer and breast cancer (Table 2). 
<smiles>NNC(=S)N[C@@H]1NNC([Al])=C([AlH2])N1</smiles>

11<smiles>[Al]C1=C([Al])N[C@@H](n2c(=S)[nH][nH]c2=S)NN1</smiles><smiles>O=c1[nH][nH]c(=S)n1[C@H]1NNC([Al])=C([AlH2])N1</smiles><smiles>Cc1n[nH]c(=S)n([C@@H]2NNC(Br)=C([Al])N2)c1=O</smiles>

Figure 1. Common structural features of the active compounds.

Table 1. The CDK2 inhibitory activity of tested compounds ( IC $_{50}$ in $\mu \mathrm{g} / \mathrm{ml}$ ).

\section{Compound. No.}

1

2

3

4

11

12

13

15

16

17

Olomoucine
$\left.\mathrm{IC}_{50} \mathbf{C D K}_{2} \pm \mathrm{SD} \mu \mathrm{g} / \mathrm{ml}\right)$

$15+1.8$

$18+2.8$

$10+1.3$

$11+2.4$

$20+3.5$

$4.0+1.8$

$11+3.8$

$4.8+1.0$

$12+5.3$

$5.0+2.8$

$5.2+2.8$

$5.0+1.0$

The data represent means values from three independent experiments plus the standard deviation (SD).

Table 2. In vitro antitumor activity data of some active compounds.

\begin{tabular}{|c|c|c|c|c|c|}
\hline \multirow{2}{*}{ Compound } & \multicolumn{4}{|c|}{ Response Parameters ${ }^{*}$ [mean log10] } & \multirow{2}{*}{$\begin{array}{l}\text { Selectivity Analysis } \\
\text { Sabpanel Sensitivity }\end{array}$} \\
\hline & ${ }^{* *}(\Delta)$ & & TGI & $\mathbf{G I}_{50}$ & \\
\hline 11 & $\begin{array}{l}0.00 \\
0.02 \\
0.69-\end{array}$ & $\begin{array}{l}\text { Non small cell lung cancer, Renal cancer } \\
\text { and Breast cancer }\end{array}$ & $\begin{array}{l}5.0 \\
5.0 \\
5.0\end{array}$ & $\begin{array}{l}5.0 \\
5.0 \\
5.0\end{array}$ & 11 \\
\hline 13 & 1.14 & $\begin{array}{l}\text { Leukemia, renal cancer, non-small cell lung } \\
\text { cancer, Breast cancer }\end{array}$ & 5.01 & 5.22 & 13 \\
\hline 16 & 0.65 & Non small cell lung cancer & 5.00 & 5.06 & 16 \\
\hline 17 & 0.37 & Breast cancer & 5.00 & 5.01 & 17 \\
\hline
\end{tabular}

$\mathrm{GI}_{50}$ : concentration giving 50\% inhibition; TGI: concentration giving total growth inhibition; LC $\mathrm{C}_{50}$ : concentration having $50 \%$ lethal effect; $\Delta$ is considered low if 1 , moderate if $>1$ and high if $\geq 3$; Subpanels showing a statistical measure of differential sensitivity with respect to the indicated response parameters. 


\section{Conclusion}

The synthesized $\alpha, \beta$-bifunctional oxygen, sulfur, halogen and nitrogen derivatives of 1,2,4-triazines have shown promising CDK2 activities. Out of eleven active compounds, four of them (11, 13, 16 and 17) have shown very good CDK2 enzyme inhibiting activity. In these compounds $\mathbf{N}$-(amino(hydrazinyl)methyl)hydrazinecarbothioamide scaffold was found to be an essential molecular feature in CDK2 enzyme inhibition activity. However these four compounds have also shown significant activity against various tumor cell-lines in subpanel assay.

\section{Acknowledgements}

The authors are grateful to King Abdulaziz University for providing research facilities to perform the present research work.

\section{References}

[1] Fuchs, T., Chowdhury, G., Barnes, C.L. and Gates, K.S. (2001) 3-Amino-1,2,4-benzotriazine 4-Oxide: Characterization of a New Metabolite Arising from Bioreductive Processing of the Antitumor Agent 3-Amino-1,2,4-benzotriazine 1,4-Dioxide (Tirapazamine). The Journal of Organic Chemistry, 66, 107-114. http://dx.doi.org/10.1021/jo001232j

[2] Leach, M., Marden, C. and Miller, A. (1986) Pharmacological Studies on Lamotrigine, a Novel Potential Anti-Epileptic Drug: II Neurochemical Studies on the Mechanism of Action. Epilepsia, 27, 490-497. http://dx.doi.org/10.1111/j.1528-1157.1986.tb03573.x

[3] Ibrahim, M.A., Abdel-Rahman, R.M., Abdel-Halim, A.M., Ibrahim, S.S. and Allimony, H.A. (2008) Synthesis and Antifungal Activity of Novel Polyheterocyclic Compounds Containing 1,2,4-Triazine Moiety. Arkivoc, Xvi, 202-215.

[4] Abdel-Rahman, R.M., Makki, M.S.T., Ali, T.E. and Ibrahim, M.A. (2012) 1,2,4-Triazine Chemistry Part III: Synthetic Strategies to Functionalized Bridgehead Nitrogen Heteroannulated 1,2,4-Triazine Systems and Their Regiospecific and Pharmacological Properties, Current Org. Synthesis, 9, 1-25. The Merck Index \& Co. Inc., White house Station, NJ, USA, (2006) 1953.

[5] Abdel-Rahman, R.M. (2001) Rrole of Uncondensed 1,2,4-Triazine Compounds and Related Heterocyclic Systems as Therapeutic Agents. Pharmazie, 56, 18-30.

[6] Abdel-Rahman, R.M. (1991) Synthesis and Anti Human Immune Virus Activity of Some New Fluorine Containing Substituted 3-Thioxo-1,2,4-triazin-5-ones, Farmaco, 46, 379-389.

[7] Mamolo, M.G., Falagiani, V., Zampieri, D., Vio, L. and Banfi, E. (2000) Synthesis and Antimycobacterial Activity of Some 4H-1,2,4-Triazin-5-one Derivatives. Il Farmaco, 55, 590-595. http://dx.doi.org/10.1016/S0014-827X(00)00074-4

[8] Abdel-Rahman, R.M., Morsy, J.M., Hanafy, F.I. and Amine, H.A. (1999) Synthesis of Heterobicyclic Nitrogen Systems Bearing the 1,2,4-Triazine Moiety as Anti-HIV and Anticancer Drugs; Part I. Pharmazie, 54, 347-351.

[9] Liu, K.C.H., Shih, Bi-J. and Lee, Ch-Hs (1993) Synthesis of Representative 10-aryl-, 10-Aralkyl- and 10-Heteroaryl$9 H$-naphtha[1',2':4,5]thiazolo[3,2-b][1,2,4]triazin-9-ones as Potential Anti HIV Agents. Journal of Heterocyclic Chemistry, 10, 1331-1335. http://dx.doi.org/10.1002/jhet.5570300525

[10] Russell, M.G., Carling, R.W., Street, L.J., Hallett, D.J., Goodacre, S., Mezzogori, E., Reader, M., Cook, S.M., Bromidge, F.A., Newman, R., Smith, A.J., Wafford, K.A., Marshall, G.R., Reynolds, D.S., Dias, R., Ferris, P., Stanley, J., Lincoln, R., Tye, S.J., Sheppard, W.F., Sohal, B., Pike, A., Dominguez, M., Atack, J.R. and Castro, J.L. (2006) Discovery of Imidazo[1,2-b][1,2,4]triazines as GABA(A) alpha2/3 Subtype Selective Agonists for the Treatment of Anxiety. Journal of Medical Chemistry, 49, 1235-1238. http://dx.doi.org/10.1021/jm051200u

[11] Koek, W., Patoiseau, J.F., Assie, M.B., Cosi, C. and Kleven, M.S. Dupont-Passelaigue, E., Carilla-Durand, E., Palmier, C., Valentin, J.P., John, G., Pauwels, P. J., Tarayre, J.-P. and Colpaert, F.C. (1998) F 11440, a Potent, Selective, High Efficacy 5-HT1A Receptor Agonist with Marked Anxiolytic and Anti-Depressant Potential. Journal of Pharmacology and Experimental Therapeutics, 287, 266-283.

[12] El-Gendy, Z., Morsy, J., Allimony, H.A., Abdel-Monem, W. R. and Abdel-Rahman R. M. (2001) Synthesis of Heterobicyclic Nitrogen Systems Bearing the 1,2,4-Triazine Moiety as anti HIV and Anticancer Drugs, Part III. Pharmazie, 56, 376-382.

[13] El-Gendy, Z., Morsy, J.M., Allimony, H.A., Abdel-Monem, W.R. and Abdel-Rahman R.M. (2003) Synthesis of heterobicyclic nitrogen systems bearing a 1,2,4-triazine moiety as anticancer drugs, Part IV. Phosphorus, Sulfur, and Silicon and the Related Elements, 178, 2055-2071. http://dx.doi.org/10.1080/10426500390228738

[14] Abdel-Rahman, R.M., Morsy, J., El-Edfawy, S. and Amine, H.A. (1999) Synthesis of Some Heterobicyclic Nitrogen Systems Bearing the 1,2,4-Triazine Moiety as Anti HIV and Anticancer Drugs, Part II. Pharmazie, 54, 667-671. 
[15] Mohared, R.M., Ibrahim, R.A. and Moustafa, H.E. (2010) Hydrazide-Hydrazones in the Synthesis of 1,3,4-Oxadiazine, 1,2,4-Triazine and Pyrazole Derivatives with Antitumor Activities. The Open Organic Chemistry Journal, 4, 8-14.

[16] El-Nagger, S.A., El-Barbary, A.A., Mansour, M.A., Abdel-Shafy, F. and Talat S. (2011) Anti-Tumor Activity of Some 1,3,4-Thiadiazoles and 1,2,4-Triazine Derivatives against Ehrlichs Ascites Carcinoma. International Journal of Cancer Research, 7, 278-288. http://dx.doi.org/10.3923/ijcr.2011.278.288

[17] Smart, B.E. (2001) Fluorine Substituent Effects (on Bioactivity). Journal of Fluorine Chemistry, 109, 3-11. http://dx.doi.org/10.1016/S0022-1139(01)00375-X

[18] Ismail, F.M.D. (2002) Important Fluorinated Drugs in Experimental and Clinical Use. Journal of Fluorine Chemistry, 118, 27-33. http://dx.doi.org/10.1016/S0022-1139(02)00201-4

[19] Dolbier Jr., W.R. (2005) Fluorine Chemistry at the Millennium. Journal of Fluorine Chemistry, 126, 157-163. http://dx.doi.org/10.1016/j.jfluchem.2004.09.033

[20] Isanbor, C. and O’Hagan, D. (2006) Fluorine in Medicinal Chemistry: A Review of Anti-Cancer Agents. Journal of Fluorine Chemistry, 127, 303-319. http://dx.doi.org/10.1016/j.jfluchem.2006.01.011

[21] Abdel-Rahman, R.M. (2001) Synthesis and Chemistry of Fluorine Containing 1,2,4-Triazine. Pharmazie, 56, $791-804$.

[22] Workman, P. (2005) Genomics and the Second Golden Era of Cancer Drug Development. Molecular BioSystems, 1, 17-26. http://dx.doi.org/10.1039/b501751n

[23] Morgan, D.O. (1997) Cyclin-Dependent Kinases: Engines, Clocks, and Microprocessors. Annual Review of Cell and Developmental Biology, 13, 261-291. http://dx.doi.org/10.1146/annurev.cellbio.13.1.261

[24] Satyanarayana, A. and Kaldis, P. (2009) A Dual Role of Cdk2 in DNA Damage Response. Cell Division, 4, 9. http://dx.doi.org/10.1186/1747-1028-4-9

[25] Abdel-Rahman, R.M. (1999) Chemistry of Uncondensed 1,2,4-Triazines Part I, Chemical Reactivity of 5,6-Diphenyl1,2,4-triazine-5-yl Containing Active Groups. Trends in Heterocyclic Chemistry, 6, 126-133.

[26] Abdel-Rahman, R.M. (2001) Chemistry of Uncondensed 1,2,4-Triazines Part IV. Synthesis and Chemistry of Bioactive 3-Amino-1,2,4-triazines and Related Compounds. Pharmaize, 56, 275-286.

[27] Musator, D.M., Kurilor, D.V. and Rakisher, A.K. (2008) Efficient Synthesis of 3-Amino-5,6-diphenyl-1,2,4-triazine. Ukrainica Bioorganica Act, 1, 61-62.

[28] Hwang, L.-C., Wu, R.-R., Jane, S.-Y. and Lee, G.-H. (2003) Crystals Structure of 3-Amino-1,2,4-triazine. Analytical Sciences, 19, x73-x74. http://dx.doi.org/10.2116/analscix.19.x73

[29] Palmer, M.H., Preston, P.N. and Steven, M.F.G. (1971) The Mass Spectra of 1,2,4-Triazines and Related Compounds. Organic Mass Spectrometry, 5, 1085-1092. http://dx.doi.org/10.1002/oms.1210050908 